Article

\title{
De Modo Qualiter Reges Aragonum Coronabuntur. Visual, Material and Textual Evidence during the Middle Ages
}

\author{
Marta Serrano-Coll \\ Department of History and Art History, Universitat Rovira i Virgili, 43003 Tarragona, Spain; \\ marta.serrano@urv.cat
}

Received: 29 October 2019; Accepted: 6 February 2020; Published: 18 February 2020

\begin{abstract}
The aim of this study is to analyze the coronation ceremonies carried out in the Crown of Aragon throughout the Middle Ages. Although the pope granted most Western monarchies the right to hold these ceremonies in their own kingdoms in 1204, our study will address the mechanisms used to appoint kings both before and after the consolidation of these ceremonies, mechanisms which reflected the power struggles between the parties involved, that is, the prince and the Church. We will examine the elements that remained constant throughout this period but we will also pay particular attention to the alterations that were made and how these had important consequences that went beyond politics and entered religious terrain. Among the changes were the kings' efforts to participate in priestly orders, the promotion and consolidation of new liturgy with content intended to legitimize the kings, and the use of new iconographies with sacred references. As will be seen, these are only a small example of the mechanisms used by the sovereigns of the Crown of Aragon to re-emphasize their links with God, which had been weakened by the transformations to the anointing and coronation ceremonials and the resulting tensions with Rome, particularly during the times of Peter IV (1336-1387).
\end{abstract}

Keywords: coronation; Crown of Aragon; laicization; sacralization; rex et sacerdos; iconography

\section{Introduction}

As Bonifacio Palacios Martín pointed out many years ago, ${ }^{1}$ it was the Visigothic monarchs under Leovigild who, in emulation of the Byzantines, introduced to the Iberian Peninsula various imperial insignias and symbols such as the throne, the robe and the crown or diadem. With this change, Palacios goes on to assert, began the creation and execution of rituals that from then on would mark the ascension to the throne of each new king. The essential parts of these rituals were the Profession of Faith, the Unction, the Coronation, the Oath (of the king and of the subjects) and the final Blessing of the monarch. ${ }^{2}$ Of these, the unction was the most original innovation given that to that point it had never been practised by either the Germanic peoples or the Byzantines, but rather had originated directly in the Old Testament.

The first references to a regal unction are to be found in the First Book of Samuel and allude to the legendary Saul: "Then Samuel took a flask of olive oil and poured it on Saul's head and kissed him, saying, 'Has not the Lord anointed you ruler over his inheritance?'”. ${ }^{3}$ These inaugural verses reveal

\section{(Palacios Martín 1975, p. 14).}

(Ferotín 1904; Sánchez Albornoz 1962).

1 Samuel 10. However, there is an even earlier reference in 9,16: "About this time tomorrow I will send you a man from the land of Benjamin. Anoint him ruler over my people Israel". 
a fundamental premise: that power came from God, an irrefutable fact that flowed inevitably into the regal liturgy during the necessary ecclesiastical intervention. In contrast, the desire and need of the monarchs to demonstrate their superiority pushed them to formalize these types of act which, far from remaining unchanged over the centuries, actually underwent notable textual and iconographic modifications. The artistic echoes of these changes and those elements that remained unaltered can be tracked throughout the Middle Ages through various artistic manifestations. ${ }^{4}$

Leaving aside the debate as to whether these rituals were a liturgy of inauguratio or translatio, ${ }^{5}$ for their principal protagonist, the king, ${ }^{6}$ in most cases they visually manifested that which Jacq and de la Perrière describe as a "communion" between the power of the king and the power of bishop; that is, the mutual recognition between two powers on whom the spiritual and material lives of the kingdom depended. ${ }^{7}$ For confirmation of this, one need only look to Hincmar of Reims (806-882), who advised Charles the Bald that kings acquired their royal dignity through the unction they received from the bishops, ${ }^{8}$ or to Gregory VII (1073-1085), who more than two hundred years later would insist that the earthly kingdom was at the service of heaven. ${ }^{9}$ It is for this reason that the kings and emperors used every possible method to present themselves as members of the clergy, which is clearly reflected in the different ceremonies that were created for their respective coronations. ${ }^{10}$ By the same token, they would also highlight the type and state of relations between kings and their subjects, and the attempts by the latter to limit the sovereignty of the former. ${ }^{11}$ In this regard, as will be commented on below, the kings of the Crown of Aragon were no exception.

\section{Precedents: Dynastic Succession in Aragon through Primogeniture. Notes on the First Kingdom of Pamplona}

In the kingdom of Pamplona, custom dictated that the throne would be inherited by the king's firstborn son, who would reign exclusively over the central kingdom while the king's other sons would reign over new territories that were added. In some cases, even while the king was still alive, he would give these other sons territories for them to rule over, although they were still required to swear their allegiance to the central kingdom. ${ }^{12}$ This is exactly what happened with Ramiro I (1035-1064), the first king of Aragon. His father, the king of Pamplona, Sancho III Garcés (1004-1035), shared his territories out among all of his sons, which in effect led to the birth of the kingdom of Castile and the emergence of the kingdom of Aragon, which were counties until 1035.

4 Panoramic view of the ceremonies of the coronation, the unction and the funeral rites of the kings of England, for example, in (Serrano-Coll 2008a, pp. 145-74).

5 The first, defended by certain anthropologists, in particular Fortes and Geertz, focuses on the taking of power through this ceremony, whereas the second, put forward by Van Gennep, emphasises the fact that in the course of the ceremony the king moves from one state to another completely new. This would be a ceremony of transit. Palacios synthesises this thesis by stating that these acts are a translatio of royal dignity to the person of the king (Palacios Martín 1986). For more on this question, see also (Le Goff 2001, p. 19ff).

6 Due to lack of space, this article will not discuss the coronation of queens, despite the fact that they were entitled to similar solemnities as the king, given that a queen was not only the king's wife, but also the mother, or should be, of the future king. In addition, a queen's anointment meant that like her husband she was a sovereign individual embodying the sacredness of the monarchy; however, she acceded to the crown through her spouse, so she remained subordinate to the king. See (Bouman 1957, p. 151). In the Crown of Aragon the principle of the queen's subordination to the king is manifested textually because, among other elements of a legal nature, the queen's ceremony followed that of her husband's investiture. It can also be observed figuratively, as will be seen. See (Silleras-Fernández 2015).

7 (Jacq and Perriere 1981, p. 74).

8 Quia enim - post unctionem quam cum coeteris fidelibus. Meruistis hoc consequi quod beatus Apostulus Petrus dicit: vos genus electus, regale sacerdotium - episcopale et spirituali unctione et benedictione regiam dignitatem potius quam terrena potestate consecuti estis. $\mathrm{P}$. L. 125. Col. 1040. From (Bloch 1961, p. 71).

9 "El poder ha sido dado de lo alto a mis señores [... ] para que el reino terrestre esté al servicio del reino de los cielos" (Power has been given from on high my lords [ ... ] so that the kingdom of the earth may serve the kingdom of heaven). Gregorii Papae I Registrum Epistolarum, III, 61. Quoted in (Pacaut 1957, p. 230).

10 See (Palacios Martín 1975).

11 Coronations as part of the royal ceremonies surrounding monarchical power are studied in (Ruiz 2012; Buc 2001). For a study focusing primarily on the Crown of Aragon, see (Orcástegui Gros 1995, pp. 633-47).

12 (Ramos Loscertales 1961). Referenced in (Orcástegui Gros and Sánchez 2001, p. 85). 
Despite the absence of documentation referring to acts of coronations, unquestionably authentic written accounts confirm the royal status of the first Aragonese king, even though he never assumed the title "Rex per gratia Dei". The reason may lie in the fact that for his father divine right was a privilege enjoyed exclusively by royalty; it was handed down to the firstborn son and thus went exclusively to García Sánchez III, heir of Pamplona. ${ }^{13}$ In this manner, as in subsequent kingdoms, according to the Navarrese tradition, in the kingdom of Aragon, when an infante was invested with the government of a given territory, he received the title of king. ${ }^{14}$ In this regard, in the 13th century, and eloquently in the frame of the government of James I (1213-1276) the Conqueror, who saw truncated his desire to be crowned by the Holy Father as we will recall subsequently, echoes of this matter can be seen: the initial lines from In excelsis Dei thesauris, a work compiled by the bishop of Huesca Vidal de Canellas between 1247 and 1252, allude to this ancient practice of which there is documentary proof. ${ }^{15}$

\section{Peter II (1196-1213): His Coronation in Rome and the Immediate Consequences}

In general terms, the surviving texts indicate that the amount of money set aside for the celebration of coronation ceremonies were not meagre and that, in their preparations, the kings attempted to employ the most renowned artists of the moment. Decorated streets and important buildings, theatre performances and other ornamental and symbolic resources combined to create an extraordinary ephemeral art that enlivened and ennobled these acts, which were frequently attended by important individuals who came from far and wide. However, there is no evidence that the coronation ceremony was practiced in Aragon until the times of Peter II who, eight years into his reign in 1204 was solemnly crowned in Rome by Innocent III (1198-1216). The chronicles describe the king as an ostentatious, gallant and generous prince ${ }^{16}$ and this explains in part why he decided to hold an event that would have so many consequences in future: "convenía a la dignidad de su estado coronarse con la solemnidad y fiesta que se requiere" (it befitted the dignity of his status to be crowned with the appropriate solemnity and celebration) commented Zurita. ${ }^{17}$ He most certainly decided to be crowned in Rome out of recognition of his natural lord: in 1163, Pope Alexander III (1159-1181) had written to his father Alfonso II (1164-1196) reminding him that the Crown of Aragon was "pertenencia bien reconocida de San Pedro" (a well-recognised belonging of Saint Peter). ${ }^{18}$

For the coronation of Peter II, it has been thought that they used some form of royal ordo such as the one from Arlés (which could have been provided by the archbishop of that place when he accompanied the king on his visit to Rome); however, in fact they used the Roman Pontifical, which only contained the ceremony for crowning emperors. ${ }^{19}$ According to the Vatican records, the Ordo coronationis Petri regis Aragonum, ${ }^{20}$ the ceremonies of unction and coronation were carried out ad

13 (Durán Gudiol 1978, p. 33).

14 Ibid., p. 35.

15 "Mientras los hijos de los reyes son niños o mancebos, no son llamados reyes, sino infantes, principalmente en España, donde el hijo del rey no alcanza esta categoría si le falta el reino, no pudiendo ser rey cumplidamente; ostentará aquel título, cualquiera que sea su edad y mereciendo por naturaleza el reino; si no lo obtienen, los hijos de los reyes serán llamados infantes" (While the sons of kings are boys or youths they are not called kings, but rather infantes, principally in Spain, where the son of the king does not obtain the status of king if he does not have a kingdom, because he is not fully able to be king; he will bear that title, whatever his age and naturally meriting the kingdom; if they do not obtain it, the sons of the kings will be called infantes) (Vidal Mayor 1989, italics are mine). Regarding coronations in Navarre, see (Orcástegui Gros 1995, pp. 637-39).

16 As confirmed by Soldevila (1926).

17 "Pareció al rey don Pedro que convenía a la dignidad de su estado coronarse con la solemnidad y fiesta que se requiere a príncipe que tiene poder que representa supremo señorí" (it seemed to King Peter that it befitted the dignity of his status to be crowned with the solemnity and celebration that is required by a prince who has power that represents supreme dominion) (Zurita [1512-1580] 1980, book II, p. 51). In the same vein Blancas also states that "convenia a la dignidad de su estado coronarse en solemnidad $y$ fiesta" (it befitted the dignity of his status to be crowned with the solemnity and celebration) (Blancas 1641, book I, p. 3).

18 ((Zurita [1512-1580] 1980, p. 36).

19 (Righeti 1956, p. 1041). See also (Palacios Martín 1975, pp. 23-25).

20 Reg. Vat. 5, fol. 202r-202v. Although it has been published on various occasions, for example in (Blancas 1641, book I, pp. 5-6), in the present study we have used the transcription given in (Palacios Martín 1975, ap. doc. II, pp. 299-301), which was in turn taken from (Mansilla 1955, p. 341). 
monasterium S. Pancratii martiris, outside the city, by the bishop of Porto, who was a suffragan of Rome, who anointed the king, and by the pope himself, who gave the king his crown, sceptre, pommel and mitre ${ }^{21}$ insignias that as soon as they arrived in the kingdom of Aragon, were deposited in the royal monastery of Sigena. ${ }^{22}$ The handing over of the latter emblems, exclusively reserved for emperors, confirms the use of the Roman Pontifical and also reveals the political intentions of the Supreme Pontiff; as has been said earlier, by giving these imperial insignias to the new king (quam speciosa fecimus preparari, proudly states Innocent III, who in addition to having commissioned and paid for them, makes a gift of them in signum gratie specialis), ${ }^{23}$ the pope created a physical and visible representation of the decrease in prerogatives enjoyed by the German emperors, which were at the time in conflict with the Holy See. ${ }^{24}$ According to some authors, ${ }^{25}$ Peter II attached great importance to the pope's concession of the mitre and pommel, a fact that is confirmed by his incorporation of the latter to his seals. (Figure 1) Nevertheless, I believe that this inclusion, which can only be seen in his seals from the end of 1207, was due not so much to his pride in the illustrious insignias given to him by Innocent III but more to a change in the political interests of the king, who was by now moving away from France and much closer toward Sicily. What is true is that this was precisely the moment when relations between the Staufen and the House of Aragon were reaching a crucial point with the betrothal of two members of the respective families, namely Lady Constance, daughter of Peter, to Frederick II of Sicily. ${ }^{26}$

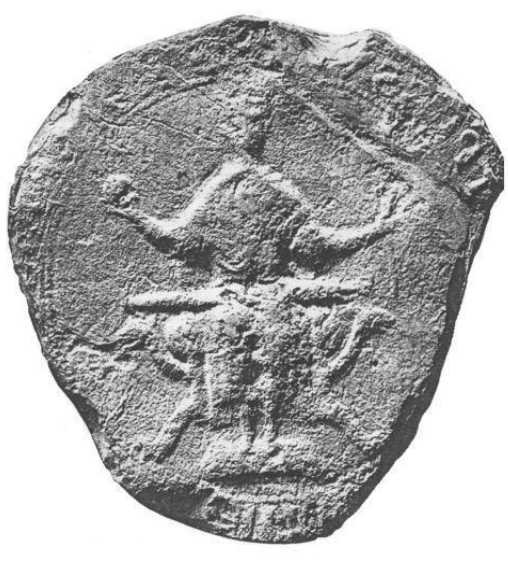

(a)

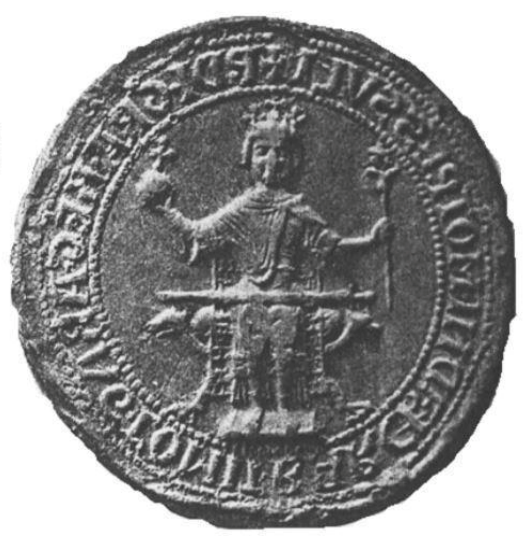

(b)

Figure 1. (a) Main seal of Peter III, obverse. 1206. From (De Sagarra i Siscar 1916-1932, n. 9). (b) Bull of Peter II, obverse. 1210 (ibid., n. 13). Both seals show the first use of the globe in the sigillography of the king of Aragon. Used with permission according with publishing rules in Spain.

21 The document indicates that predictum regem permanum Petri Portuensis episcopi fecit iniungi, quem postmodum ipse manu propia coronavit, largiens ei regalia insignia universa, mantum videlicet, et colobium, ceptrum et pomum, coronam et mitram (ibid., p. 300). Paludamentum purpureum of the Byzantine emperors, the colobium or marina purpura auro decora (short cloak), the globe, the crown and the mitre are all listed by Durán Gudiol $(1989$, p. 18). Regarding the insignias and the difficulties in interpreting them, see (De Molina 1998, pp. 148-49).

22 This is known from a document addressed to James I, dated 1 June 1218 and issued by Ozenda, prioress of the convent. In it the abbess agrees to send the king the crown and other royal insignias belonging to James' father for his coronation: concedimus et convenimus vobis Iacobo regi Aragonum et comiti Barchinone et domino Montispesulani, ut quacumque hora vos queritis vobis coronam et mitram et sceptrum et pomum similiter que fuerunt honorabilis patris vestri Petri regis Aragonum et comitis Barchinoneci eterna sit requies. On the back of the document it states: Carta corone domini regis. Carta coronee, mitre et ceptri domini regis Petri antiqui. References in (ibid., pp. 147-56).

23 As the Pope indicates in the document in which he allows the kings and queens of Aragon to be crowned in Zaragoza: Reg. Vat. 7, fol. 31, n. 92 and fol. 95. Published in (Blancas 1641, book I, p. 7).

24 As pointed out by Schramm (1960, p. 129).

25 (De Sagarra i Siscar 1916-1932, vol. I, p. 103). See also (Palacios Martín 1975, p. 51).

26 For more on this hypothesis, see (Serrano-Coll 2015, p. 68). The king may have copied the sigillographic models of Federico II for his largest stamps. Subsequently, after adopting the imperial insignias, he transferred them to the iconography of his bulls. 
Returning to the ceremony celebrated in Rome, having been anointed and crowned, the new king, accompanied by a splendid retinue, arrived at Saint Peter's where he was appointed a knight, renewed his feoffment to the Holy $\mathrm{See}^{27}$ and renounced his patronage of the churches of the kingdom. In this way, Peter II became miles sancti Petri and also miles sancti Petri mirabiliter factus, according to the surviving document. ${ }^{28}$ Some months later, on 16 June 1205, Innocent III issued a bull in which he gave the kings the right to request to be crowned in Zaragoza by the archbishop of Tarragona: de speciali mandato per Tarraconensem archiepiscopum apud Caesaraugustam solempniter coronentur. ${ }^{29}$ One month after this, he ratified the privilege, adding a clause that empowered the archbishop of Tarragona to also crown the queens of Aragon: per manus eiusdem archiepiscopi eas liceat coronari. ${ }^{30}$ This established a purely feudal system or procedure which, through its documents, proclaimed that royal power depended on the Church in terms of both its origin and destiny.

Leaving to one side the motives that induced Peter II to carry out this act in Rome, ${ }^{31}$ the linking of his coronation to the reaffirmation of his vassal status to the Holy See and the fact that this ceremony should be carried out, de speciali mandato, ${ }^{32}$ in the Seo de Zaragoza by the archbishop of Tarragona, Peter II's successors continued to struggle to elude control by the universal powers so that they could complete their acts with the most absolute sovereign autonomy. ${ }^{33}$

\section{James I (1213-1276): The Renunciation of His Coronation and the Proclamation of the Right to Conquest}

Given the deterioration in relations between Innocent III and Peter II towards the end of his life, the protection offered by Innocent to the young James I when on 12 September 1213, at the battle of Muret he unexpectedly became an orphan begs for attention. However, in reality the pope was motivated not only by the feoffment of the kingdom to the Holy See, but also by his obligations under the principle of the miserabiles persona $e^{34}$ to offer protection to widows and orphans, particularly if they had held positions of responsibility. ${ }^{35}$ It is for this reason that he quickly assumed protection of the young king of Aragon and spared no effort in assisting in the affairs of the kingdom. ${ }^{36}$ The protection afforded by Innocent III led James I to refer to him as the "mellor apostoli; que de la saó que feem aquest llibre en cent anys passats no hac tan bo apostoli en l'església de Roma" (best apostle; that in the hundred years prior to writing this book, there has never been such a good apostle in the Church of Rome) ${ }^{37}$ The close bonds between the king and the church can be seen from the first important episode in the young monarch's reign, the courts of Lleida in 1214, convened by the cardinal and papal

27 Sancho Ramírez had already enfeoffed his kingdom to the Holy See. A letter has survived which states that the monarch informed Urban II (1088-1099) about this matter, offering him an annual tribute of 500 mancusos (mancusos Iaccensis monete) and, each of his knights, another mancuso annually. He adds that this is in perpetuity: "Haec constituo et confirmo et a me et a successor meo obseruanda perpetuo". The document was the first to be published by Paul Ewald in 1880 according to Paul Kehr, 1928, Das Pastum un die Könogsreichen Navarra und Aragon, a work published in Berlin that was translated to Spanish (Kehr 1946). By allying himself with a distant but powerful institution such as the Papacy, Sancho Ramírez was perhaps seeking to strengthen his own position in relation to his most powerful neighbours. From then on until Peter III, there is only one clear case of a king of Aragon swearing his vassalage to the Holy See, namely Peter I, in 1098 (Mansilla 1955, pp. 58-59; Kehr 1946, pp. 184-86).

(Palacios Martín 1988, p. 179). See, also, (Orcástegui Gros 1995, pp. 639-40).

29 (Palacios Martín 1975, ap. doc., III, p. 301).

30 Reg. Vat. 7, fol. 97, n. 100. As in (ibid., ap. doc., III, p. 302).

31 Much has been written about Peter's motives, which bring together his interests in the south of France and the Mediterranean, with Mallorca and Sicily as strongholds. Synthesis in the early but still pre-eminent reference work by Soldevila (1934, vol. I, p. 222ff).

32 (Durán Gudiol 1989, p. 19).

33 See (Palacios Martín 1975, p. 27).

34 Regarding this principle, see the chapter Principles of Ecclesiastical Jurisdiction: The Protection of Miserabiles Personae and Jurisdiction ex Defectu Iustitiae in (Helmholz 2010, pp. 116-44).

35 (Carlyle and Caryle 1967, vol. III, pp. 182-83).

36 For more on this subject, see (Smith 2016).

37 That is, the best pope in the last hundred years up to the very moment in which the king wrote his chronicle (Ferran 2007b, chp. 10, p. 61). The king adds that "era bon clergue en los sabers que tanyen a apostoli de sabere, e havia sen natural, e dels sabers del món havia gran partida"; that is, "there was no better pope in the Church of Rome, because he was a good cleric, versed in 
legate, Pedro Beneventano. ${ }^{38}$ The documents state that the cardinal exhorted those present from the other kingdoms to swear loyalty to the new king, ${ }^{39}$ but the most notable aspect, which has largely been ignored by historians, is the form of acclamatio given to James when he was held aloft by his relative, the bishop of Pamplona, an incident that the king would record in his well-known Llibre dels feyts. ${ }^{40}$ Also notable from the account are the architectural descriptions of the space in which the episode occurred, most likely the Palace of la Suda, which the king states "de volta qui ara és, e llaores era de fust" (is now vaulted, but was then of wood) and other details, such as the window through which he emerged before his subjects and the new use to which the building was put over time, which demonstrates not only James policy of improving palatial spaces but also his interest in recalling spaces that hosted the royal ceremonies that he participated in even as a boy. ${ }^{41}$

The bonds between the monarch and the Holy See remained intact during the initial years of James I's reign. The courts of Lleida in 1214 led to revolts and divisions, which prompted the pope to remind the nobles and cities of the loyalty that they owed to the king and urged them to abandon their conjurationes against him, basing his intervention on the fact that his kingdom cum idem rex apostolice sedis protectione consistat et regnum suum Romane sit ecclesie censuale, that is, it was under the protection of Rome. ${ }^{42}$ Nevertheless, tensions emerged relatively soon after the death of Innocent III as his successor, Honorius III (1216-1227), issued a bull to the king, who was still only nine years old, in which beneath his apparent expression of support can be detected a threatening tone. ${ }^{43}$

Shortly afterwards, at the age of thirteen, in 1221 and in Tarazona, James I was appointed a knight. The ceremony was held a little over a year after Ferdinand III (1217-1252) had adorned himself with the cingulum militare, 44 an act that was repeated by the young James in his own investiture, as his chronicle tells us. ${ }^{45}$ In doing so, he fulfilled a common ritual throughout feudal society, because the act of presenting the boy with arms on reaching a certain age was the public recognition of his capacity to govern. ${ }^{46}$ Moreover, and of particular concern to us, this act in which the king put on the sword which he himself had taken from the altar demonstrated the suppression of any ecclesiastical intervention from the moment the arms were handed over, which, as has been said, symbolized the acceptance of his capacity and suitability to take on the tasks of government. The young James did this, as he states

matters corresponding to a pope, and he was gifted with good sense and knew much about the knowledge of the world" (ibid.).

38 Regarding this figure, who was delegated by the pope to act on behalf of James I, see (Smith 2016).

39 Ibid.

40 According to James I's chronicle, because James was only six years old, the Bishop of Pamplona, a relative of his, held him aloft so that all could see him. And it was that that they swore loyalty to the king. "[... ] on nos tenia en el braç l'arquebisbe n'Espàrrec, que era del llinatge de la Barca e era nostre parent" (where we were held in the arms of Archbishop Esparrec, who was of the lineage of Barca and was relative) (Ferran 2007b, chp. 11, p. 63).

41 The act took place "sus el palau de volta qui ara és, e llaores era de fust, a la finestra on ara és la cuina per on dóna hom a menjar a aquells qui mengen en lo palau" (in the palace that is now vaulted, but was then of wood, in the window where now is the kitchen from which food is given to those who eat at the palace) (ibid.). For more on this palace and the historiographical debates around its construction, I refer the reader to the epigraph El Castell del Rei in the doctoral thesis of Niña Jové (2014, pp. 153-59)

42 Biblioteca Nacional de Madrid, Ms. 13042, fol. 7v. Published in (Palacios Martín 1975, p. 69 and ap. doc., VI, pp. 302-3). Highly informative is another document from 1217 in which Honorius III says the following about the kingdom of Aragon: quod regnum tuum ad Romanam ecclesiam noscitur pertinere (Mansilla 1955, pp. 86-87, n. 106), quoted in (Palacios Martín 1975, p. 71, n. 29).

43 Carissimo in Christo filio, illustri regi Aragonum. Utinam prava consilia tuam adolescentiam non seducant, nec impellant ad aliquid faciendum per quod videaris ingratus et immemor beneficiorum et graciae quae apostolica sedes tibi studuit exhibere, te de illorum manibus quos inimicos reputas eruendo ac reddendo tibi terram tuam pariteer et te terrae! (Most esteemed son in Christ, the illustrious King of Aragon. I hope that bad advice does not seduce your adolescence nor impel you to do anything that makes you appear ungrateful and forgetful of the benefits and graces that the Holy See strove to give you, freeing you from the hands of those who you state are your enemies and returning your kingdom to you, and you to your kingdom!" (Soldevila 1968, pp. 143-44 and n. 22).

44 With the sole help of his mother and guardian, Lady Berenguela, who adjusted it for him. See (Palacios Martín 1988, p. 188).

45 "E fo la nostra cavalleria en Sancta Maria de l'Horta de Tarassona, que oïda la misa de Sent Espirit, nós cenyim l'espasa que prenguem de sobre l'altar" (And it was our cavalry in Santa Maria de l'Horta de Tarasson who after the mass of the Holy Spirit, put around our waist the sword which we took from the altar) (Ferran 2007b, p. 19).

46 I quote (Palacios Martín 1988, p. 160). 
in his chronicle, to avoid prompting any recollections of his father's investiture in Rome, in which Peter II formally recognised his vassal status. That James did not want to maintain this vassalage with respect to the Holy See is clear throughout his reign, especially in all of his ultimately unsuccessful attempts to be crowned.

As is well known, to carry out the ceremony, the sovereign had to coronam a sede apostolica requirentes, that is, request prior permission from Rome. ${ }^{47}$ However James I, despite trying on various occasions to get the pope to crown him, ${ }^{48}$ never paid the tribute or recognized his feoffment to the Holy See. The last of his attempts, and the best known, took place between 1 and 10 May 1274 when he went to Lyon to see Gregorius X (1272-1276), who was there to generate support for a crusade to the Holy Land. Again James was unsuccessful because the pope would only agree to do it if he confirmed his vassalage and paid the outstanding debt of tribute, which according to James' accounts was some 40,000 mazmudinas. The attempt ended with the king returning with the crown under his arm, disappointed that such trifling matters, menuderies in his own words, should have been given more importance than his service to God and the Roman Church. ${ }^{49}$ It is true that James I, who voluntarily decided not to crown himself (no ens volguem coronar), ${ }^{50}$ saw his wishes to be crowned go unfulfilled, but he strongly held rejected being bound by the obligations and commitments of his father Peter II, arguing that both he and his predecessors had won their kingdoms from the Muslims by the sword, ${ }^{51}$ and the strength of these views would mark the route to be followed by all of his successors. It is important to recall that the idea that the sovereigns' sword gave him supreme dominion over his kingdoms had emerged much earlier, specifically during the reign of Alfonso I (1104-1134), who also had tense relations with Rome. ${ }^{52}$ Nevertheless, as I stated in an earlier study, ${ }^{53}$ the reign of James I was a real turning point because it also had important iconographic consequences.

As has been stated, it is certain that the right of primogeniture was sufficient for the kings of Aragon to be able to govern. It is also true that the right to conquest, which re-evaluated the sword as a royal insignia (Figure 2) and is basically an affirmation that land belongs to he who conquers it, ${ }^{54}$ was a means of legitimizing the monarchy in territories recently acquired by the crown. However, James I was always at pains to emphasize his connection with the holy, despite not wanting to subject himself to Church (Figure 3). In this regard, it is significant that the terms "Dei gratia regis Aragonum" first appear in the seals of the king of Aragon around his image, ${ }^{55}$ words that are highly eloquent if one takes into account that the conquests of his new kingdoms, Valencia and Mallorca, were allegedly assisted by the intervention of Saint George on the side of the Christians. ${ }^{56}$ The appearance of Saint George has been understood as a means of mythologizing the king, ${ }^{57}$ but in my opinion it actually points to divine will and support and also supplants the need for recognition by the pope in order for

47 For more on the bull issued by Innocent III and its consequences for the kings of Aragon after James I, see (Palacios Martín 1969).

48 In fact, even in 1229 he sent an envoy to Rome to request that Gregory IX perform his coronation (Palacios Martín 1975, p. 78).

49 "E nós dixem-los que no érem venguts a la sua cort per metre-nos en treüt, mas per franquees que ell nos donàs; e, pus fer no ho volia, voliem-nos-en més tornar menys de corona que ab corona" (And we told him that we had not come to his court to pay him tribute, but rather for the franchises that he had given us; but he did not want to do it, so we preferred to return without the crown than with the crown) (Ferran 2007b, para. 538).

50 "E sobre açò romàs que no ens volguem coronar" (And so it came over us that we did not want to be crowned) (ibid.).

51 "Car mon llinatge la conqués ab l'espasa" (Since my predecessors conquered it with the sword) (Ferran 2007a, p. 543).

52 Although his will gave the Holy See another chance to strengthen its position. See (Palacios Martín 1975, p. 49).

53 (Serrano-Coll 2012).

54 As stated in (Palacios Martín 1976, pp. 274-96). See also (Serrano-Coll 2008b, pp. 53-55).

55 These terms, however, were common in diplomatic signatures (Mateu y Llopis 1954).

56 This saint had already collaborated with a king of Aragon, Peter I (1094-1104), during the conquest of Huesca. Nevertheless, this event is described eloquently and for the first time in the Crónica de San Juan de la Peña commissioned by Peter IV between 1369 and 1372: "Vencida aquella batalla vinose San Jorge [ . . . ] a la batalla de Huesca et vidieronlo visiblement" (With that battle won [of Antioch], Saint George came [ . . . ] to the battle of Huesca and they saw him) (Orcástegui Gros 1986, ap. 18, lines 59-60, p. 40).

57 For more on this interpretation, see, among others, (Yarza Luaces 1995, vol. I, p. 104; Molina i Figueras 1997; Serra Desfilis 2002, p. 25). 
the monarch to act as sovereign. Although the ecclesiastical institutions did not recognize this divine assistance or support the dissemination of this miracle, the iconographic evidence indicates that it was believed and celebrated throughout the 14 th and 15 th centuries. ${ }^{58}$

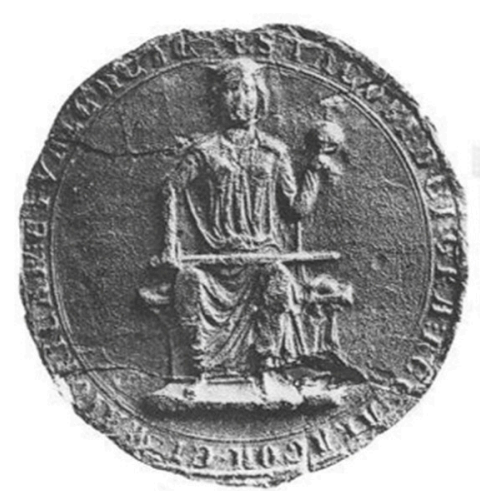

(a)

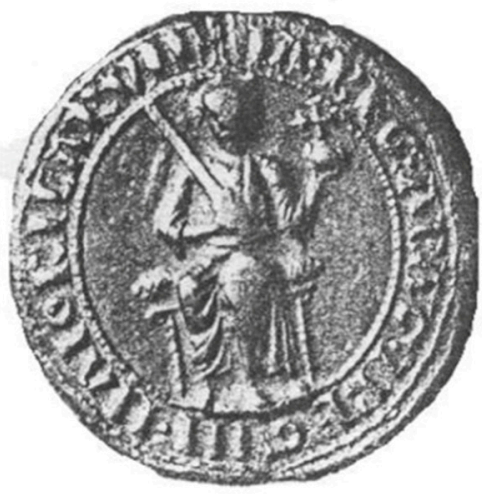

(b)

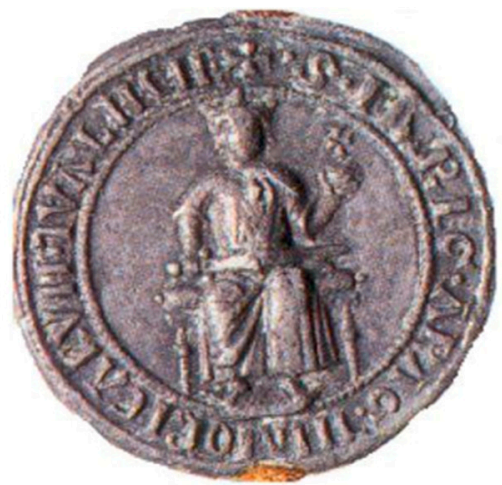

(c)

Figure 2. (a) Main seal of Jaime I, obverse. 1238-1276. From (De Sagarra i Siscar 1916-1932, n. 28). (b) Bull of James I, obverse. 1231-1238 (ibid., n. 25). (c) Bull of Jaime I. 1255. From (Conde 1992, p. 114). All the seals show the preeminence of the sword in the seals of James I. Used with permission according with publishing rules in Spain.

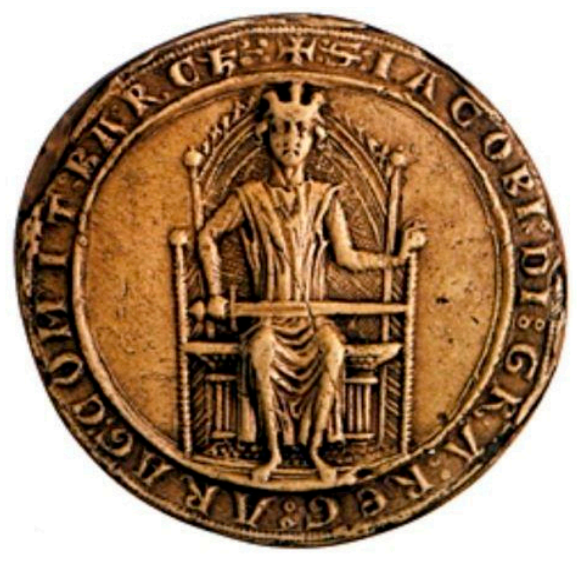

(a)

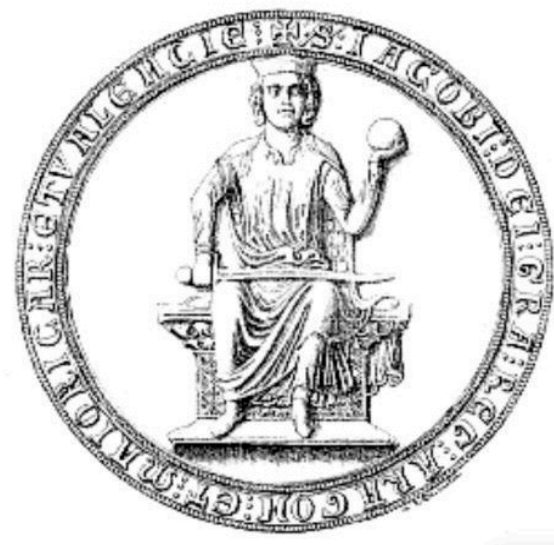

(b)

Figure 3. (a) Main seal of James I. Obverse. 1229. D/11222 (c) Archives Nationales de France. Legende says: + S:IACOBI:DI:GRA:REG:ARAG:COMIT:BARCH. (b) Main seal of James I. Obverse. 1248-1272. Legend says: + S:IACOBI:DEI:GRA:REG:ARAGON:ET MAIORICAR:ET VAENCIE. Design taken from (De Dainville 1952). Used with permission according with publishing rules in Spain.

\section{From Peter III (1276-1285) to James II (1291-1327): The Development of the Ceremonial in Favour of Royal Sovereignty}

Curiously, the son of James I, Peter III, nicknamed the Great, started to act as sovereign from the moment his father died but did not call himself king until he was finally crowned in a ceremony held

58 The altarpiece of Saint George or the Centenar de la Ploma by Marzal de Sax, from around 1410-1420 (Victoria and Albert Museum); the altarpiece of Saint George in Jérica, from around 1423 (Museo del Ayuntamiento de Jérica, Castellón); and the predella of the altarpiece of Saint George by Nisart around 1470 (Museo Diocesano de Palma de Mallorca) are the best known examples. See the epigraph "El Conquistador amparado por la divinidad" in (Serrano-Coll 2008b, pp. 208-26). More recently, (Serrano-Coll 2011, pp. 715-37). 
several months after the death of his predecessor one Sunday in November $1276 .{ }^{59}$ We have little information on this event, although it is important to point out that it was the first coronation held by a king of Aragon in his own kingdom and that its clearly reflects the position of the monarchy. The ceremony was held in the Seo de Zaragoza, capital of the kingdom and the crown, ${ }^{60}$ but not by the archbishop of Tarragona, as had been prescribed by the pope, but rather per ministerium venerabilis $P$ [etri], Dei gratia episcopi cesaraugustane eiusdem sedis. ${ }^{61}$ In reality, Peter III demonstrated in this and future ceremonials his opposition to the bull issued by Innocent III and corroborated his freedom eis placuerit, according to the surviving documentation, ${ }^{62}$ to choose Zaragoza as the city where the ceremony would be held and to elect his own bishop as the officiating minister.

However, it was his successor Alfonso III (1285-1291) who in 1286 instituted the greatest number of innovations to the ceremonial by integrating four elements that would come to form the essence of all futures liturgies: the unction, the coronation, his reception into the order of chivalry and the mutual swearing of loyalty between kings and subjects. ${ }^{63}$ He neither asked for permission to be crowned, as had been stipulated by Innocent III, nor was he crowned by the metropolitan of Tarragona but rather the bishop of Huesca. But the most important innovation is the appearance of the formula nec pro ipsa Ecclesia nec contra Ecclesiam which, as Blancas stated, is only implicit in the protest of his predecessor. ${ }^{64}$ The role played in the ceremony by the sword, "la pus rica, e la mills guarnida que anc emperador ne rei portàs" (the richest and the best decorated that any emperor or king has ever borne) ${ }^{65}$ is also clearly important, although where it states in the 12th chapter of the Ordo ad regem bendicendum of the Pontifical of Huesca that the king receives this insignia from the bishop, a note in the margin changes this and specifies that the king is to pick the sword up himself after it has been blessed by the bishop. ${ }^{66}$ In fact, according to the chronicle of Ramón Muntaner, Alfonso III not only took the sword from the altar, just James II had done, but also "hac feta la sua oració, besá la croera de la sua espaa e cenyi's ell mateix la dita espaa" (having completed his prayer, kissed the quillon of the sword and then girdled himself with it). ${ }^{67}$ In doing so he expressed the divine nature imbued in him through this emblem by emphasising the shape of the cross formed by the cross-guard; that is, the point of union between the blade and the grip. Furthermore, through these gestures, the Crown of Aragon also resembled Castile where, according to some scholars, they used a mechanically controlled sculpture of Saint James holding a sword to confer

59 "[ . . . ] no quiso recibir la corona ni título real hasta que fuese primero coronado en Zaragoza" ([ ... ] he did not receive either crown or royal title until he had been crowned in Zaragoza) (Zurita [1512-1580] 1980, book IV, chp. II). The coronation took place on 15 or 22 November according to (Durán Gudiol 1989, p. 25).

60 This was confirmed some time later by Peter IV when he stated that Zaragoza caput est regni Aragonum quod regnum est titulum et nomen nostrum principale: Archivo de la Seo de Zaragoza, Cartoral Grande, fol. 324v. Cited in (Palacios Martín 1975, p. 107, n. 39).

61 (Eubel 1913, p. 153), cited in (Palacios Martín 1975, p. 100, n. 19).

62 Highly significant are the terms recorded by Bonifacio Palacios: [ . . ] sed possint succesores nostri qui pro tempore fuerint, recipere unctionem, benedictionem et coronationem in quacumque civitate eis placuerit totius nostri jurisdictionis et per ministerium archiepiscopi vel episcopi notri districtus (ibid., p. 103, n. 29).

63 For reasons of space, I will not discuss the system used by the king to swear before his subjects. Instead, I refer the reader to the early and still definitive study by Giesey (1968).

64 [... ] quam à vobis venerabili I A. Dei gratia Oscensi Episcopo facimus, non intendimus à vobis recipere tanquam ab Ecclesia Romana, nec pro ipsa Ecclesia, nec contra Ecclesiam. Item etiam protestamur, quod ex en quia in Civitate Caesaraguste in Ecclesia Maiori Sancti Salvatoris Coronam et Militiam recipimus nullum nobis, vel successoribus nostris [ . . ] (Blancas 1641, book I, p. 22). Analysed in (Palacios Martín 1975, pp. 121-22).

65 (De Bofarull 1860, chp. CCXCVII, p. 572).

66 Archivo Catedral de Huesca, sign. 10, fol. 60v, according to (Lacarra y de Miguel 1972, p. 22, n. 34). It is possible that this pontifical was the one adapted for the coronation of Alfonso III, given that the following ceremony (after James II, who was not crowned) used the imperial pontifical "of Constantinople" which is kept in the Toledo codex. Palacios hypothesises that the pontifical was used by the see of Huesca, which is where the bishop who crowned the king came from. It therefore needed to be modified, which explains the notes in the margins intended to adapt it to the ceremony (Palacios Martín 1975, p. 128). Transcription of the same in (ibid., ap doc., XXI, pp. 317-21). More details on this text in (Durán Gudiol 1989, pp. 20-22).

67 Once girdled round his waist, the king of Aragon took it from its scabbard and brandished it three times, promising, respectively, to challenge the enemies of the Catholic faith, support orphans and widows and impart justice for all (De Bofarull 1860, chp. CCXCVII, p. 574). 
the accolade on the king, thus ensuring not only divine assistance in any battles he might undertake, but also that he was appointed king without the need for any civil or ecclesiastic intermediary. ${ }^{68}$

When Alfonso III died in June 1291, his brother and successor James II was governing Sicily, where he had been crowned king some years before. Perhaps due to the problems that had occurred in the times of his predecessor, who used the royal title before being sworn in, thus causing serious conflicts with the Aragonese, James II was not crowned in Aragon and he did not call himself king until he took possession of the kingdom and had sworn to uphold its privileges. ${ }^{69}$ In making this choice, it is probable that James II felt that a new unction and ceremony were not necessary given that he had already been crowned king in Sicily, although we cannot rule out the possibility that it was part of his a strategy to get closer to Rome; that is, by avoiding a ceremony that would revive earlier conflicts with the pope, he would assist himself in his policy of rapprochement with the Holy See, which he sought to achieve throughout his reign. As Palacios indicates, the unction and coronation in Sicily meant that he could choose not to have himself crowned again in Aragon and thus sidestep certain difficulties. ${ }^{70}$ What should be emphasised is that on returning to Barcelona he lodged a formal protest to make it clear that he had received the kingdom not because his brother had bequeathed it to him but because it was his by right of succession. ${ }^{71}$ Likewise, leaving to one side his attitude of absolute respect towards the Holy See, to whose spiritual authority he always submitted, when taking possession of his kingdoms James II had planned the ceremonies in such a way as they did not imply the recognition of a dominant power by another lesser one. ${ }^{72}$ His swearing-in ceremony, which recognised the Aragonese fueros (privileges and exemptions) as the primary basis for all law in the kingdom, has been described as the moment in which the "myth of the king" began to take form. The prestige of the monarch in the eyes of the people and the face of opposition by the self-serving nobles, who had usurped his role as protector of the fueros and the law, also originate in the birth of this myth. ${ }^{73}$

\section{Alfonso IV (1327-1336) and Peter IV (1336-1387): The Culmination of the Process of Consecrating the King and Everything around Him}

We know that the successor to James II, Alfonso IV, intended to be crowned with the greatest solemnity possible thanks to the chronicles of his son Peter IV and Ramón Muntaner, who both witnessed the event. ${ }^{74}$ The documents reveal that the king regarded the ceremony as a liturgy that increased royal dignity because he clearly stated that he had reached the summit of this even before being crowned; in some letters sent just after succeeding his father he alludes to arriving at "apex of royal dignity". ${ }^{75}$ We may thus conclude that this ceremony was now understood within a wider

68 The first to use it could have been Alfonso X, according to (Ballesteros Beretta 1963, p. 54). In fact, in his chronicle he mentioned that the figure of Santiago "gave him a ritual blow on the cheek" (Catalán 1946, chp. CXX, p. 1332). Brief but illustrative comments on the truth of this mechanism, in reality a transformed Virgin Mary, can be found in, among others, (Carrero Santamaría 2012).

69 And all this despite the fact that both Zurita and Blancas state that he was crowned in San Salvador de Zaragoza "in the usual manner". The matter was contradicted and clarified in (Palacios Martín 1969, p. 496).

70 (Palacios Martín 1975, p. 191).

71 (Blancas 1641, book I, p. 25).

72 See (Palacios Martín 1975, p. 194).

73 (Ibid., p. 200). The king not only swore on the privileges but also became their most staunch defendant. In the same vein as Palacios are the studies of Sesma Muñoz (1988, p. 226).

74 The chronicler Muntaner attended as a representative of Valencia, with his children: "E aixi mateix hi fom nosaltres" (And likewise we went there) (De Bofarull 1860, chp. CCXCIV, p. 566). He also how impressive the event was in the following terms: "Què us en diría? Que jamés en Espanya no fo així gran festa en un lloc, de bona gent, com aquesta és estada" (What can I say to you? That never in Spain has there been as great celebration as this has been) (ibid.). Peter IV in the prologue to his chronicle also refers to it: "Item és feta menció del fer de la coronació del dit senyor rey N'Anfós, com fos una de les notables festes qui es feessen en la Casa d'Aragó, e non den ésser més en oblit, car solament hic es feta mencio del sit senyor rey, nostre pere, en aquests dos fets qui foren fort notables, ço es, de la conqueste de Sardenya e de la sua coronació" (To mention the coronation of King Alphonse, as one of the most notable celebrations ever to be held by the House of Aragon, and will never be forgotten, since our King Peter mentions two notable feats, that is, the conquest of Sardinia and his coronation) (De Bofarull 1850, p. 25).

$75[\ldots]$ antequam pervenissemus ad apicem regie dignitatis is a sentence that is repeated in more than one document issued by the king before he was crowned. References in (Palacios Martín 1975, p. 207, n. 9). 
European context of monarchic exaltation in which royal figures were adorned with all the symbols of grandness and accompanied by a splendid and magnificent setting that visually reflected the extraordinary honour surrounding the institution of the monarchy. Particularly relevant in this regard are the words of Ramón Muntaner, who defines Alfonso's coronation as having had "la major solemnitat e festa que hanch rey prengues en Espanya nul temps, ne encara en altres provincies com yo puch saber" (the greatest solemnity and celebration that any king in Spain or in any other provinces has ever had). ${ }^{76}$ The monarchy asserted its power through a ceremony and celebration ${ }^{77}$ that amazed all those who attended or participated in it, clerics and courtiers alike, in private or public, whilst it ensured the recognition of royal authority by the king's subjects through aesthetic displays of great power and magnificence. It is hardly surprising that Peter IV described the event as so remarkable that it "no deu ésser mes en oblit" (must never be forgotten). ${ }^{78}$

According to the chronicler Ramón Muntaner, in addition to organizing a celebration worthy of his status, Alfonso IV had wanted to establish Easter Sunday as the day of his coronation, thus drawing a parallel between the death and resurrection of Christ and the death of Alfonso's father and the public resurrection of the royalty. ${ }^{79}$ On the same day that the ceremonies concluded, his period of mourning for his father, James II, was lifted. ${ }^{80}$ In this regard and in keeping with other European courts, although with different nuances, ${ }^{81}$ the clothing worn for the ceremony is particularly telling because it was the richly decorated vestments of a deacon, that is, the alb, the dalmatic, the stole (worn across the shoulder and sword) and the maniple. ${ }^{82}$

Regarding the struggle between the absolute sovereign and the pontifical theocracy, which maintained the fiction that it was the pope who awarded the king his kingdom when his representative, the metropolitan, placed the crown on his head. It was also Alfonso who introduced the most significant change in terms of gestures and spectacle by picking up the crown himself and depositing it on the altar and placing it on his own head, thus demonstrating that he was the only sovereign power. ${ }^{83} \mathrm{He}$ would do with the other insignias exactly the same as he had done with the crown. The officiating minister, the infante Don Juan, archbishop of Toledo and brother of the sovereign, merely blessed him,

76 (De Bofarull 1860, chp. CCXCIV, p. 567).

77 Regarding ritualizations and propagandistic and legitimating intentions, a chapter that continues to be of interest is that of (Nieto Soria 1993, pp. 23-26).

78 (De Bofarull 1850, p. 24).

79 "ell pensa que aixi con los sants apostols e dexebles de nostre Senyor Déus Iesuchrist estaven desconsolats, que axi los seus sotsmeses estaven ab gran tristor per la mort del senyor rei son pare; e que axi com Iesuchrist, lo jorn de la Pascha, primer vinent, que fo diumenge, a tres diez en abril del any MCCCXXVIII, que ell confortas e alegras si mateix, e sos germans e tots los seus sotsmesos. E ordona quel dia davant dit de Pascha, que prelats e richs homens e cavallers e missatgers e ciutadans e homens de viles honrrades de regnes fossen a la ciutat de Çaragoça; e aquell dia beneyt ell se faria cavaller, e pendria la corona beneyta e astruga ab la major solemnitaat" (he thinks that in this way the holy apostles and disciples of our Lord Jesus Christ were disconsolate, that in this way his subjects were very sad due to the death of the king his father; and that like Jesus Christ, on the next day of Easter, which was Sunday, 3rd April 1328, he comforted and cheered them, and his brothers and all his subjects. And he ordered on that day of Easter, that prelates, rich men, knights, messengers, citizens and men from honourable kingdoms were in the city of Zaragoza; and that blessed day he became knight and took the blessed and fortunate crown with the greatest solemnity) (De Bofarull 1860, chp. CCXCIV, p. 564).

80 "y entravan todos de luto por la muerte del Rey Don Jayme II. Y assi lo estuvieron los días, que hubo de aquella semana hasta el Viernes Santo a la tarde, que el Rey mandò, que el dia siguiente Sabado Santo dicha el Alleluya, se lo quitasen, y se aparejasen muy de propósito para la fiesta" (And they all entered in mourning due to the death of James II. And they were in this way from that week until the afternoon of Good Friday, when the king ordered that the following day, Easter Saturday, their period of mourning should be lifted and they should get ready for the celebration) (Blancas 1641, book I, p. 30).

81 According to Marc Bloch, "tout contribuait donc, et de plus en plus, à évoquer à propos des vêtements portés par le souverain, le jour où il recevait l'onction et la couronne, l'idée des ornements sacerdotaux ou pontificaux" (Bloch 1961, p. 204). See also (De Azara 1913, p. 221).

82 The king wore an alb "es vestí camís, aixi com si degues dir missa" (he wore a chemise as if he was going to say mass) and a stole, which "era tan rica e ab tantes perles e peres precioses, que seria fort cosa de dir ço que valia" (was so rich and with so many precious pearls and stones, that it would be difficult to say what it was worth). The maniple was also "molt rich e ab gran noblesa" (very rich and with great nobility) (De Bofarull 1860, chp. CCXCVII, p. 573).

83 "E con fo revestit e hach comensada la missa, lo dit senyor rei, ell mateix, pres la corona del altar e las posa al cap" (And as he was dressed and had commenced mass, the King took the crown off the altar and placed it on his head) (De Bofarull 1860, chp. CCXCVII, p. 574). 
although once the crown was on the king's head, he and the king's other brothers, Pedro and Ramón Berenguer, set about straightening it up, "adobarenla li" (they dressed him with it), in the words of the chronicle. ${ }^{84}$ No previous ceremonial, either in Iberia or north of the Pyrenees had seen the officiating bishop substituted by the king in the act of placing the crown, although the practice would soon be imitated in 1332 by Alfonso XI in Castile. ${ }^{85}$

Highly aware of the implications of this gesture, the archbishop of Tarragona tried to restore the function to himself and his successors for the subsequent coronation of Alfonso IV's son and heir, Peter IV: "E quaant lo offici se dech començar, venchnos lo Archabisbe e dichnos ens pregá, que ell nos posas la corona al cap davant tot lo poble, allegant rahons algunes, donantnos que axis devia fer" (And when the office began, the Archbishop came to us and asked us if he could place the crown on our head before all the people, giving certain reasons that it should be done thus), the king himself said. ${ }^{86}$ The infante was also aware of the consequences of such an act and, on the advice of the nobleman Ot de Montcada, he energetically opposed the proposal "car seria prejudici de la corona que Nos fossem coronats per ma de prelats" (since it would be to the detriment of the crown were we to be crowned by the prelates). ${ }^{87}$ The intention, as has been said repeatedly, ${ }^{88}$ was to suppress anything that might give the impression that the kingdom had been awarded by the Church whilst still maintaining the monarch's sacred nature of "rex gratia $D e i$ ", through a direct relationship with God without any intermediary. Peter IV strengthened and institutionalised the innovations put in place by his father by including them in the Ceremonials of consecration and coronation of the kings of Aragon and through iconography and the written word (Figure 4). ${ }^{89}$
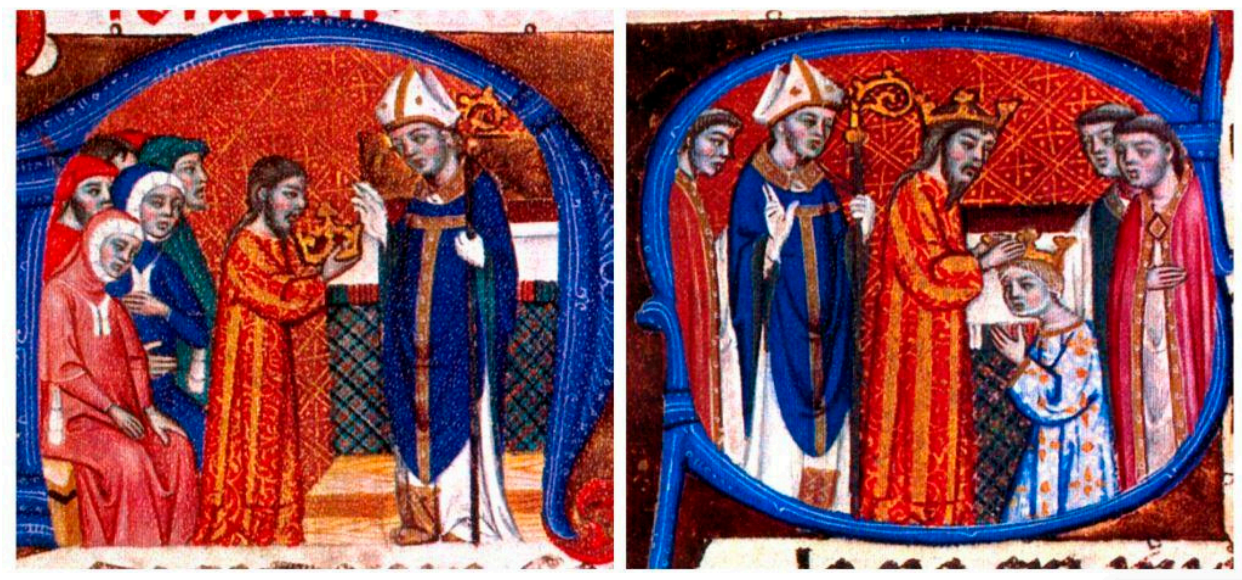

Figure 4. Ceremonial de consagración y coronación de los reyes de Aragón. Ms. 14425, fols. 19r and $35 \mathrm{v}$. Second half of 15th century. (C) Fundación Lázaro Galdiano. Both illuminations show the most important moment of the ceremonies; that is, when the king takes the for himself crown and when the king places the crown on the new queen's head. Permission granted.

84 "e com aço hach feyt, lo senyor arquebisbe de Toledo e el senyor infant En Pere e el senhyor infant En Ramon Berenguer adobarenla li" (and as that was done, the Archbishop of Toledo and the infante Peter and the infante Ramon Bereguer dressed him in it) (ibid.).

85 See the recent studies by Pérez Monzón (2010) and Carrero Santamaría (2012).

86 (De Bofarull 1850, p. 80).

87 Ibid.

88 As stated in (Palacios Martín 1975, p. 217). A recent study of this matter is that of Aurell and Serrano-Coll (2014).

89 The illuminated versions with scenes representing the act of self-coronation are preserved in the Fundación Lázaro Galdiano de Madrid, Ms Reg. 14425 and the Biblioteca Nacional de Francia, Ms. Esp. 99. 
In the ceremonial that was prepared for the occasion, which has been dated to between January and April $1336^{90}$ (although it was rewritten for three subsequent versions ${ }^{91}$ ), any intervention by the consecrating bishop regarding the placing of the crown was removed. Instead, it stipulated that only the king could touch the crown, which he himself would put on his head and adjust without the help of any other person: "e débesela meter en la cabeza, e que no le ayude ninguna persona, ni larcebispe ni infant, ne ninguna persona otra de cualquier condición que sea, ni adobar ni tocar la pont". 92 This document is, therefore, a prescription of what would happen during his coronation. Peter IV commissioned numerous works for his own personal pleasure but also for propagandistic purposes, hence the nickname of Peter the Ceremonious, and he wasted no time in generating a ceremonial that would serve his successors so that "en el començamiento del su regimiento antes de todas las cosas [sea] informado por qual forma $y$ solempnidat la [corona] debe prender" (at the beginning of his reign, before anything else he knows in what manner and with which solemnity he should take the crown). ${ }^{93}$ Perhaps the king had not been able to forget the conflict with the prelate in sacristy moments before the ceremony; the archbishop was aware that the practice initiated by Alfonso IV to prevent the officiating cleric from placing the crown diminished his authority and so pressured the king to change the liturgy just before the ceremony. In his chronicle, Peter IV eloquently relates how he felt disturbed and in "gran perill" (great danger), because the archbishop spoke to him in a tone that only honoured the church and its archbishop, to the great detriment and subjugation of the kingdom. ${ }^{94}$

To get round the impasse, Peter IV pretended to accede to the demands of the archbishop, who proposed an alternative proceeding; he would take the crown from the altar and hand it to the king before everybody. ${ }^{95}$ But when he approached the altar to receive the crown, he said to the archbishop that he only needed to accompany him to that point and that he must not adjust or touch the crown because he would do it himself. ${ }^{96}$ Thus Peter IV, aware that this was the culmination of the process of exalting the new king before his subjects, not only took the crown and other insignias (despite the fact that the words being pronounced at that moment were inconsistent with the actions that were

90 I follow the timeline offered by Palacios Martín (1975, p. 239), who asserts that the first ceremonial text was produced in Zaragoza shortly before the Peter IV's coronation and was used in that ceremony. He would subsequently return to the text to make new annotations for the later versions. For more on the arguments that Palacios uses to support his hypothesis, see (ibid., p. 239ff).

91 Halfway through his reign, Peter IV wanted to reorganise and regulate his house and court and added to his ordinances the ceremonial text for the coronation of kings. The text was more solemn and included the coronation of queens, which did not feature in the previous version because the king was not married. He took the opportunity to rectify certain concepts that had not been properly formulated in the first version, perhaps because it was written hastily (ibid., p. 259). In addition to the unfinished version kept in El Escorial (Man. \& III.3), there are three complete versions: one in Latin, another in Catalan and a third in Aragonese. They may have been connected with the three capital cities of the three kingdoms at the core of the Crown of Aragon; that is, Zaragoza, Barcelona and Valencia. See (Palacios Martín 1994a, p. 14).

92 These terms are from the codex of the Escorial: "dita la oración debe el rey prender la corona del altar e debesela meter en la cabeza, e que no le ayude ninguna persona, ni larzebispe ni infant ne ninguna persona otra de cualquier condicion que sea ni tocar la pont" (after the prayer is said, the king must take the crown from the altar and put it on his head, and nobody must help him, not the archbishop, nor the infante nor anybody else of any status, nor may they touch it?) (Palacios Martín 1975, p. 237). Likewise, the codex of Saint Michael of the kings explains that: Acabada esta oración, el Rey tomará de encima del altar esta corona y él mismo se la ponrá en la cabeza sin que nadie le ayude" (after the prayer, the king will take the crown from the altar and he himself will place it on his head with anybody else's assistance) (Palacios Martín 1994b, p. 222). In a similar manner, the codex in the Museo Lázaro Galdiano says: "E aquesta oración dita el rey prenga la corona de sobre l altar e ell mismo pósela en su cabeça sin ayuda de otra persona" (And once this prayer has been said the king must take the crown from the altar and he himself place on his head without the help of any other person) (San Vicente Pino 1992, vol. II, p. 33).

93 Fragment extracted from the manuscript in the Fundación Lázaro Galdiano de Madrid, Ms Reg. 14425, fol. 19r.

94 "[...] veèmnos en tan gran perill, ço es, per lo dia quins era lo pus honrat que null altre que nos esperasen en aquest setge, e que aquell que teniem per pare, quant en aquest mòn, diguès aytals paraules en honrar la sua esglesia e sòn archabisbat en gran detrment e subiugació de nostre règne" (we saw oneself in great danger, that is, on the most honourable of all days we did not expect this attack of whom we consider our father, that in that moment he should say those words with the aim of honouring the church and his archbishopric in great detriment and subjugation of our kingdom (De Bofarull 1850, p. 81).

95 "E tantost fet lo dit atorgament, Nos isquem de la sacrestia" (And having given in to him, we left the sacristy) (ibid.).

96 "E Nos diguèmli que prou. Bastaba, e que nons adobás nens tocas nostra corona, que Nos lens adobariem. E axi no lin donam licencia, de la qual cosa ell fo molt mogut, e non gosà fèr res apares" (And we said enough. That was enough now, and that he should not adjust or touch our Crown, that we would do it on our own. And in this way we denied him licence, and he was surprised and did not dare to do anything) (ibid.). 
being carried out ${ }^{97}$ ), but also prevented anyone else from touching them. As had been the case in the ceremonial of his father, the sacred nature of the king was emphasized by his clothing, in particular the stole, which he wore like a deacon, "asi como evangelistero" (like an evangelist) in the words of the ceremonial. By using this ecclesiastical clothing, which had been permitted by Rome in certain coronations since the beginning of the 11th century, Peter IV recognised and visually manifested his sacerdotium. I believe that with Peter IV we witness a type of political theology, that is, the visual manifestation of the monarch as rex et sacerdos (Figure 5), which would become one of the most spectacular achievements in the sensory universe. ${ }^{98}$

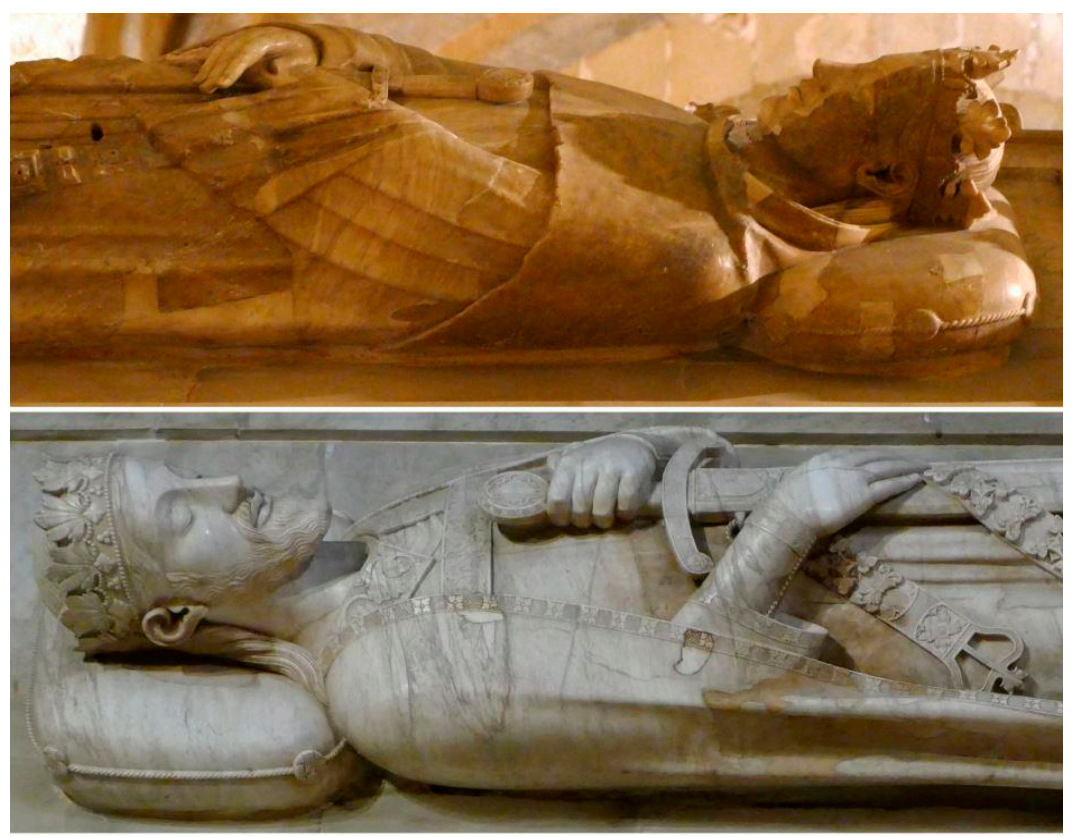

Figure 5. Monastery of Santa María de Poblet. James I as king and as monk, recumbent effigies which show the concept of Rex et Sacerdos. They were commissioned by Peter IV in the second half of the 14th century and restored in the 20th Century: the darkest parts are original; the lighter parts are reconstruction by the sculptor Frederic Marès. (C) Santa María de Poblet. Photo: Marta Serrano Coll. Permission granted.

His sons, John I (1387-1396) and Martin I (1396-1419) made no further innovations. John I intended to be crowned in 1388 but the ceremony never took place. In contrast, his brother Martin I was crowned, and the event followed the stipulations of the ceremonial written by his father. It seems that the ceremony was not as ostentatious that of his father, ${ }^{99}$ although it must still have been extraordinary given the remarks of the chroniclers, who refer to the "grandes prevenciones" (grand previsions) by the king, who also "procuro de aver grandes joyas y preseas de mucha estima" (sought to have great jewels and precious things), including the sword of the Emperor Constantine. ${ }^{100}$ Much more spectacular (although without changes to the ceremony) were the celebrations organized for Ferdinand I (1412-1416) who as a member of the Castilian dynasty of the Trastámaras succeeded

97 Depending on the ceremonial text used, the archbishop proclaimed that crown was placed on his head by the unworthy hands of the bishops: licet ab indignis episcoporum manibus capiti tui imponitur. I cite (Palacios Martín 1975, p. 245, n. 32). In the second ceremonial text and its copies, these terms are replaced by others that reflected what really happened during the ceremony.

98 Although there are precedents in his own dynasty, which I discussed in (Serrano-Coll 2017, pp. 337-62).

99 (Durán Gudiol 1989, p. 32).

100 Although we are told that nowhere does it state that this sword was ever used, despite sending the archdeacon of Zaragoza, don Ponce de Tahuste, to Sicily to fetch it. We also know that he sent emissaries to obtain jewels from various places (Blancas 1641, book I, p. 63). 
Martin I after the Compromise of Caspe. To legitimate his rule, he undertook a series of initiatives to extol a dynasty whose greatest achievements would occur between two key moments in his reign, namely his coronation in Zaragoza and his burial in the monastery of Santa María de Poblet, where the royal bodies of the Aragonese monarchs were interred.

\section{Conclusions}

As is known, coronations were an important demonstration of sovereignty over the subjects, and their liturgy (of varying complexity) could be complemented by gestures and other minor acts which made visible the power of the king and the "state of health" of relations between the king and the ecclesiastical powers, whose role was progressively reduced in ceremonies until they were relegated to the strictly religious.

Although lack of space prevents me from adding specific comparisons with other kingdoms, it is particularly evident that in the Crown of Aragon papal power constantly hindered the development of the Aragonese coronation ceremony. Although at first glance the picture described here does not seem to have an overarching sense, the relationship between the kings and the popes (sometimes fluid, sometimes very tense) was the reason for the introduction of significant innovations in the coronation rites, whose roots go back to the Roman pontifical of the 13th century. In some cases, to prevent their subjugation to Rome, kings were not crowned, but this meant that their power was subsequently questioned by their subjects. Birth right was key to their claim to power, as was their submission to the law when they swore to respect the customs of the respective kingdoms before the Cortes. James I introduced the sword as a characteristic emblem of the Crown of Aragon: this insignia grew in prominence as a symbol of authority because justified his sovereignty over newly conquered lands. But this meant that his authority was solely secular and did not have support of the church. During the 14th century, with the monarchy's increasingly autocratic nature, a kind of new secularization can be observed in the "ordo coronationis" whose peculiar features had been articulated little earlier during the reign of Alfonso IV, who abandoned the vassalage commitment to Rome and adopted a new symbolic language. These new developments were recorded in the scrolls of the Ceremonial de consagración y coronación commissioned by Peter IV and strengthened the monarchy; however, they also threatened a clear break with the church which the king sought to avoid through various mechanisms. One of the most significant was the promotion of the cult of Saint George who, as emissary and representative of God, his holy assistance has to be perceived as a way of sanctifying and giving divine approval to the authenticity and legitimacy of James' right to govern these territories as a king without being crowned. Thus, the relationship between the monarchic and the divine was finally clearly established. Peter IV promoted this sacred help, as well as featured the emergence of a form of political theology that will reach, in the manifestation of the monarch as rex et sacerdos, one of its clearest and most spectacular expressions in the sensory realm. During the 14 th century will be seen other artistic depictions (such as almost all the funerary devices adopted over the course of the century) that showed the king, or the institution he represented, under a quasi-sacred halo.

Funding: This research was funded by the Catalan Government, in the framework of the Pre-Consolidated Research Group Edificis i escenaris religiosos medievals en la Corona d'Aragó [GRPRE 2017 1724].

Conflicts of Interest: The author declares no conflict of interest.

\section{References}

Aurell, Jaume, and Marta Serrano-Coll. 2014. The Self-coronation of Peter the Ceremonious (1336): Historical, Liturgical and Iconographical Representations. Speculum. A Journal of Medieval Studies 89: 66-95. [CrossRef] Ballesteros Beretta, Antonio. 1963. Alfonso X el Sabio. Barcelona: Salvat.

Blancas, Jerónimo. 1641. Coronaciones de los Serenissimos Reyes de Aragón. Zaragoza: Diego Dolmer.

Bloch, Marc. 1961. Les Rois Thaumaturges. Étude sur le Caractère Surnaturel Attribué a la Puissance Royale Particulièrement en France et en Angleterre. Paris: Armand Colin. 
Bouman, Cornelius A. 1957. Sacring and Crowning. The Development of the Latin Ritual for the Anointing of Kings and the Coronation of an Emperor before the Eleventh Century. Groningen-Djakarta: J.B. Wolters.

Buc, Philippe. 2001. The Dangers of Ritual. Between Early Medieval Text and Social Scientific Theory. Princeton: Princeton University Press.

Carlyle, Robert Warrand, and Alexander James Caryle. 1967. Il Pensiero Politico Medieval. Bari: Laterza.

Carrero Santamaría, Eduardo. 2012. «Por las Huelgas los juglares». Alfonso XI de Compostela a Burgos, siguiendo el libro de la coronación de los reyes de Castilla. Medievalia 15: 143-57. [CrossRef]

Catalán, Diego. 1946. Crónica de Alfonso XI. Madrid: Gredos.

Conde, Rafael. 1992. Sello de plomo de Jaime I. In Cataluña medieval. Barcelona: Lunwerg.

De Azara, José Jordán Urries. 1913. Las Ordenaciones de la Corte aragonesa en los siglos XIII y XIV. Boletín de la Real Academia de las Buenas Letras 7: 220-29.

De Bofarull, Antonio. 1850. Crònica de D. Pedro IV, el Ceremonioso ó del Punyalet. Escrita en Lemosin por el Mismo Monarca, Traducida al Castellano y Anotada. Barcelona: Imprenta de Alberto Frexas.

De Bofarull, Antonio. 1860. Crónica Catalana de Ramón Muntaner: Texto Original y Traducción Castellana, Acompañada de Numerosas Notas. Barcelona: Diputación Provincial de Barcelona.

De Dainville, Maurice Oudot. 1952. Sceaux conserves dans les Archives de la ville de Montpellier. Montpellier: Lafitte-Lauriol.

De Molina, Rafael Conde y Delgado. 1998. Las insignias de coronación de Pedro I-II “El Católico", depositadas en el Monasterio de Sijena. Anuario de Estudios Medievales 28: 147-56. [CrossRef]

De Sagarra i Siscar, Ferran. 1916-1932. Sigil-Lografia Catalana. Inventari, Descripció i Estudi dels Segells de Catalunya. Barcelona: Estampa d'Henrich.

Durán Gudiol, Antonio. 1978. Ramiro I de Aragón. Zaragoza: Guara.

Durán Gudiol, Antonio. 1989. El rito de la coronación del rey en Aragón. Argensola: Revista de Ciencias Sociales del Instituto de Estudios Altoaragoneses 103: 17-40.

Eubel, Conrad. 1913. Hierarchia Catholica Medii Aevi, I. Munster: Sumptibus et typis Librariae regensbergianae.

Ferotín, Marius. 1904. Le "Liber Ordinum" en usage dans l’Eglise wisitothique et mozarabe d'Espagne du cinquième au oncième siècle. Monumenta Ecclesiae Liturgica 5.

Ferran, Soldevila. 2007a. Bernat Desclot, Crònica. In Les Quatre Grans Cròniques. Revisió Filològica de Jordi Bruguera i Revisió Històrica de M. Teresa Ferrer i Mallol. Barcelona: Institut d'Estudis Catalans.

Ferran, Soldevila. 2007b. Jaime I, Libre dels feyts del rei en Jacme. In Les Quatre Grans Cròniques. Revisió Filològica de Jordi Bruguera i Revisió Històrica de M. Teresa Ferrer i Mallol. Barcelona: Institut d'Estudis Catalans.

Giesey, Ralph E. 1968. If Not, Not. The Oath of the Aragonese and the Legendary Laws of Sobrarbe. Princeton: Princeton University Press.

Helmholz, Richard H. 2010. The Spirit of Classical Canon Law. Athens: Georgia.

Jacq, Christian, and Patrice de la Perriere. 1981. Les Origines Sacrées de la Royauté Française. Paris: Léopard d'Or.

Kehr, Paul. 1946. El papado y los reinos de Navarra y Aragón hasta mediados del siglo XII. Estudios de Edad Media de la Corona de Aragón II: 74-186.

Lacarra y de Miguel, José María. 1972. El juramento de los reyes de Navarra (1234-1329). Madrid: Real Academia de la Historia.

Le Goff, Jacques. 2001. La structure et le contenu idéologique de la cérémonie du sacre. In Le Sacre Royal à L'époque de Saint Louis. Edited by Jacques Le Goff, Éric Palazzo, Jean-Claude Bonne and Marie-Noël Colette. Le Temps des Images. Paris: Gallimard.

Mansilla, Demetrio. 1955. La documentación pontificia hasta Inocencio III. Monumenta Hispaniae Vaticana 1: 1-665.

Mateu y Llopis, Felipe. 1954. Rex Aragonum. Notas sobre la intitulación real diplomática en la Corona de Aragón. Spanische Forschungen der Görresgesellschaft. Herausgegeben von ihrem spanischen Kuratorium. Heindrich Finke (+), Wilhelm Neuss, Georg Schreiber. Gesammelte Aufsätze zur Kulturgeschichte Spaniens 9: 117-43.

Molina i Figueras, Joan. 1997. La ilustración de leyendas autóctonas: El santo y el territorio. Analecta Sacra Tarraconensia 70: 5-24.

Nieto Soria, José Manuel, ed. 1993. Legitimación y propaganda como criterios de valoración de una tipología ceremonial. In Ceremonias de la Realeza. Propaganda y Legitimación en la Catilla Trastámara. Madrid: Nerea.

Niña Jové, Meritxell. 2014. L'escultura del Segle XIII de la Seu Vella de Lleida. Lleida: Universitat de Lleida.

Orcástegui Gros, Carmen. 1986. Crónica de San Juan de la Peña (Versión Aragonesa). Edición Crítica. Zaragoza: Diputación Provincial, Institución Fernando el Católico. 
Orcástegui Gros, Carmen. 1995. La coronación de los reyes de Aragón: Evolución política-ideológica y ritual. In Homenaje a Don Antonio Durán Gudiol. Huesca: Instituto de Estudios Altoaragoneses.

Orcástegui Gros, Carmen, and Esteban Sarasa Sánchez. 2001. Sancho Garcés III el Mayor. Rey de Navarra. Burgos: La Olmeda.

Pacaut, Marcel. 1957. La Théocratie. L'Eglise et le Pouvoir au Moyen Age. Paris: Montaigne.

Palacios Martín, Bonifacio. 1969. La bula de Inocencio III y la coronación de los reyes de Aragón. Hispania. Revista Española de Historia 113: 485-504.

Palacios Martín, Bonifacio. 1975. La Coronación de los Reyes de Aragón. 1204-1410. Aportación al Estudio de las Estructuras Politicas Medievales. Valencia: Anubar.

Palacios Martín, Bonifacio. 1976. Los símbolos de la soberanía en la Edad Media española. El simbolismo de la espada. In VII Centenario del Infante D. Fernando de la Cerda. Ciudad Real: Instituto de Estudios Manchegos.

Palacios Martín, Bonifacio. 1986. Los actos de coronación y el proceso de secularización de la monarquía catalano-aragonesa (s. XII-XIV). Bibliothèque de la Casa de Velazquez. 1. État et Église Dans la Gènese de L'état Modern 1: 115.

Palacios Martín, Bonifacio. 1988. Investidura de armas de los reyes españoles en los siglos XII y XIII. Gladius vol. esp.: 153-92.

Palacios Martín, Bonifacio. 1994a. El "Manuscrito de San Miguel de los Reyes" de las "Ordinacions" de Pedro IV. Coordinated with Bonifacio Palacios Martín. Valencia: Scriptorium.

Palacios Martín, Bonifacio. 1994b. Estudio histórico de las Ordenaciones. In El "Manuscrito de San Miguel de los Reyes" de las "Ordinacions" de Pedro IV. Coordinated with Bonifacio Palacios Martín. Valencia: Scriptorium.

Pérez Monzón, Olga. 2010. Ceremonias regias en la Castilla Medieval. A propósito del llamado Libro de la Coronación de los Reyes de Castilla y Aragón. Archivo Español de Arte 83: 317-34. [CrossRef]

Ramos Loscertales, José María. 1961. El Reino de Aragón Bajo la Dinastía Pamplonesa. Salamanca: Universidad de Salamanca.

Righeti, Mario. 1956. Historia de la Liturgia. Madrid: Biblioteca de Autores Cristianos, vol. II.

Ruiz, Teófilo. 2012. A King Travels: Festive Traditions in Late Medieval and Early Modern Spain. Princeton: Princeton University Press.

San Vicente Pino, Angel. 1992. Ceremonial de Consagración y Coronación de los Reyes de Aragón. Ms. R. 14.425 de la Biblioteca de la Fundación Lázaro Galdiano, en Madrid. Coordinated with Eduardo Vicente de Vera. Transcripción y estudios. Zaragoza: Diputación General de Aragón.

Sánchez Albornoz, Claudio. 1962. La “Ordinatio principis" en la España goda y postvisigoda. Cuadernos de Historia de España 35-36: 5-36.

Schramm, Percy Ernst. 1960. Las Insignias de la Realeza en la Edad Media Española. Madrid: Instituto de Estudios Políticos.

Serra Desfilis, Amadeo. 2002. Ab recont de grans gestes. Sobre les imatges de la història i de la llegenda en la pintura gòtica de la Corona d'Aragó. Afers. Fulls de Recerca i Pensament 17: 15-35.

Serrano-Coll, Marta. 2008a. El códice AGN-B2 y la iconografía de coronaciones y exequias en el arte bajomedieval. In Ceremonial de la Coronación, Unción y Exequias de los Reyes de Inglaterra. Estudios Complementarios al Facsímil. Coordinated with Eloisa Ramírez. Pamplona: Gobierno de Navarra.

Serrano-Coll, Marta. 2008b. Jaime I el Conquistador. Imágenes Medievales de un Reinado. Zaragoza: Institución Fernando el Católico.

Serrano-Coll, Marta. 2011. La iconografia de Jaume I durant l'edat mitjana. In Jaume I, Commemoració del VIII Centenari del Naixement de Jaume I. Barcelona: Institut d'Estudis Catalans.

Serrano-Coll, Marta. 2012. Art as Means of Legitimization in the Kingdom of Aragon. Coronation Problems and their Artistic Echos during the Reigns of James I and Peter IV. Ikon. Journal of Iconographic Studies 5: 161-72. [CrossRef]

Serrano-Coll, Marta. 2015. Effigies Regis Aragonum. La Imagen Figurativa del Rey de Aragón en la Edad Media. Zaragoza: Institución Fernando el Católico.

Serrano-Coll, Marta. 2017. Rex et Sacerdos. A veiled ideal of kingship? Representing priestly kings in Medieval Iberia. In Political Theology in Medieval and Early Modern Europe. Discourses, Rites and Representations. Edited by Montserrat Herrero, Jaume Aurell and Angela C. Micheli. Turnhout: Brepols. 
Sesma Muñoz, Ángel. 1988. El sentimiento nacionalista en la Corona de Aragón y el nacimiento de la España Moderna. In Realidad e Imágenes del Poder. España a Fines de la Edad Media. Coordinated with Adeline Rucquoi. Valladolid: Ámbito.

Silleras-Fernández, Nuria. 2015. Creada a su imagen y semejanza: la coronación de la reina de Aragón según las ordenaciones de Pedro el Ceremonioso. Lusitania Sacra 31: 107-28.

Smith, Damian J. 2016. Inocencio III, Pedro Beneventano y la Historia de España. Vergentis 2: 85-79.

Soldevila, Ferran. 1926. La figura de Pere el Catòlic en les cròniques catalanes. Revista de Catalunya 4: 497ff.

Soldevila, Ferran. 1934. Historia de Catalunya. Barcelona: Alpha.

Soldevila, Ferran. 1968. Els primers anys de Jaume I. Barcelona: Institut d'Estudis Catalans.

Vidal Mayor. 1989. Vidal Mayor. Versión Romanceada en Aragonés del Códice "In Excelsis Dei Thesauris". Siglo XIII. Edición Facsímil Autorizada por el J. P. Getty Museum de Santa Mónica, California. Huesca: Diputación Provincial de Huesca and Instituto de Estudios Aragoneses.

Yarza Luaces, Joaquín. 1995. La pintura española medieval. El mundo gótico. In La Pintura en Europa. La Pintura Española. Directed by Alfonso E. Pérez Sánchez. Milán: Electa.

Zurita, Jerónimo. 1980. Anales de Aragón. Edited by Ángel Canellas López. Zaragoza: Institución Fernando el Católico. book II. First published 1512-1580.

(C) 2020 by the author. Licensee MDPI, Basel, Switzerland. This article is an open access article distributed under the terms and conditions of the Creative Commons Attribution (CC BY) license (http://creativecommons.org/licenses/by/4.0/). 